\title{
Ovarian Mucinous Cystadenofibroma
}

National Cancer Institute

\section{Source}

National Cancer Institute. Ovarian Mucinous Cystadenofibroma. NCI Thesaurus. Code C40041.

A benign neoplasm of the ovary characterized by the presence of cystic structures lined by mucinous columnar epithelial cells in a fibrotic stroma. 